University for Business and Technology in Kosovo

UBT Knowledge Center

UBT International Conference

2018 UBT International Conference

Oct 27th, 10:45 AM - 12:15 PM

\title{
Challenges of Real Estate Appraisers in Kosovo
}

Marjan Ivezaj

University for Business and Technology, marjan.ivezaj@ubt-uni.net

Follow this and additional works at: https://knowledgecenter.ubt-uni.net/conference

Part of the Civil and Environmental Engineering Commons

\section{Recommended Citation}

Ivezaj, Marjan, "Challenges of Real Estate Appraisers in Kosovo" (2018). UBT International Conference. 43. https://knowledgecenter.ubt-uni.net/conference/2018/all-events/43

This Event is brought to you for free and open access by the Publication and Journals at UBT Knowledge Center. It has been accepted for inclusion in UBT International Conference by an authorized administrator of UBT Knowledge Center. For more information, please contact knowledge.center@ubt-uni.net. 


\title{
Challenges of Real Estate Appraisers in Kosovo
}

\author{
Marjan Ivezaj \\ UBT - Higher Education Institution, Lagja Kalabria, 10000 p.n., Prishtina, Kosovo \\ marjan.ivezaj@ubt-uni.net
}

\begin{abstract}
Kosovo is a new country with a goal to integrate quickly into the large family of EU countries. To achieve this, old work practices are changing, and new practices are also being applied in different fields of human activity. Real estate property plays an important role in the process of economic development and is considered as sacred. To be treated this way, the property must be evaluated correctly. Following the examples of EU countries, the Kosovo institutions have organized training, testing and licensing of the first domestic real estate appraisers. The basic data to perform this profession are scarce, incomplete or even misleading. Currently, only banks require real estate appraisal of properties. The property left as a mortgage loan should be valued by licensed professionals. In the future it is expected that the appraisal of real estate property will be mandatory for every real estate transaction between parties. This paper seeks to highlight the challenges faced by real estate appraisers in their day-to-day work in Kosovo's conditions.
\end{abstract}

Keywords: Real estate, construction, property value, economy, law

\section{Definitions}

Real estate is the land including the air over it and the underground (including the mineral rights) and all the buildings or structures built upon it.

An appraisal is estimation of a value. It is defined as a valuation, because valuation does not declare a value nor fix it.

An appraisal is only a person's opinion based on any skills, training, data, dedication and / or objectivity that this person possesses.

The purpose of most real estate appraisals is to estimate Market Value.

Market Value is defined as the most likely sale price of a property in a competitive and open market.

The basis of appraisal of the Market Value is defined by the European Valuation Standards: "The estimated amount for which the property should exchange on the date of valuation between a willing buyer and a willing seller in an arm's length transaction after proper marketing wherein the parties had each acted knowledgeably, prudently and without being under compulsion."

According to the Regulation "On the Procedures and Criteria for Licensing of Natural Persons as Real Property Valuers", eligible person to become licensed appraisal in Kosovo should have a university degree in: Construction, Geodesy, Architecture, Economics, Agriculture and Forestry, Mathematics and Law.

Licenses for appraisal are issued by Ministry of Finance, Supervisory Board for Licensing of Real Estate Appraisers in coordination with Kosova Chamber of Commerce after eligible person follows all modules of training for appraisal and passes successfully tests from all modules. 


\section{Procedures}

Steps to perform an appraisal of real estate are: signing the contract for assignment, gathering of information, processing of information, drafting of the report and calculating the value of the property. The orderer of the assignment is not necessarily the owner of the property. He may be an interested party to purchase the property or the bank issuing the loan to the owner of the property.

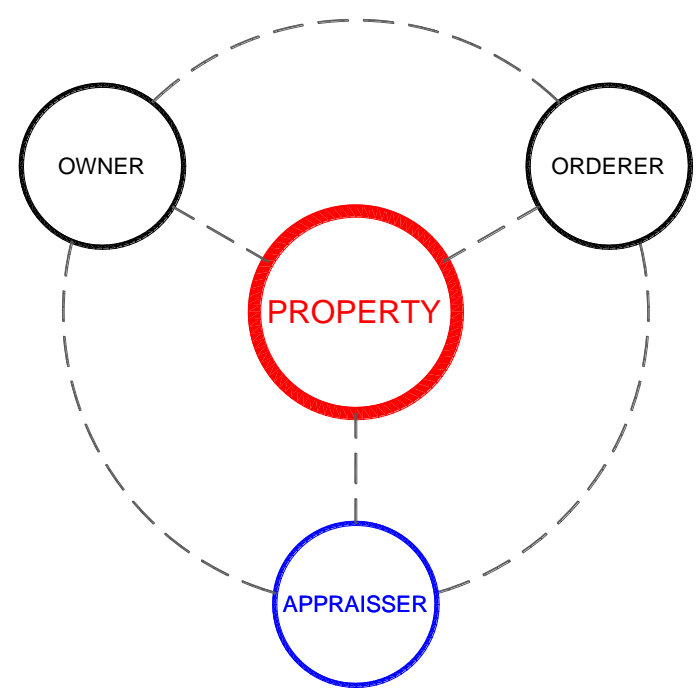

Fig. 1. Property stakeholders in appraisal process

As in any profession, information determines the steps of solving the problem, and in our case this information affects heavily the final value of the property.

Depending on used methods of the appraisal we encounter different challenges. The most commonly used method is the comparison method. The biggest challenge is to gather accurate and comprehensive information regarding the property.

When the orderer of the assignment is also the owner of property, he thinks he has the right to influence on the value of the property and possibly offers higher service fees to artificially increase the value of the property. Other case is when intervention is made to lower the value of property thus lowering possible taxes. The appraiser should never be affected by any intervention by violating the code of ethics and endangering license revocation.

\section{Market conditions}

Institutions which have property sale transactions data avoid disclosure of this information to third-parties. Therefore gathering of information in most cases is incomplete and not up-to-date. A good source of information could be property tax bill. But since the appraisal is not done individually for each property, but mass appraisal is used, the value of the property in the property tax document does not reflect at all the market value of the property. There are times when market value is even more than double of the calculated value of property for tax purpose. 
Real estate agencies have a big role in establishing market value, but most of them are unqualified and not licensed to perform professional appraisal. They are not taking into consideration all details required and they tend to increase property values because their provision is defined as percentage of property value.

The existing legal framework is inadequate. The law on appraisal does not exist yet. Profession of real estate appraiser is regulated only by administrative and regulatory instructions.

For this reason this profession is not widely required, except in banking institutions. There are rare cases of property appraisal requests that are outside the scope of the bank activities.

Based on this, the number of current licensed appraisers is high. The law needs to come into force to increase the need and demand for even more appraisers in the future.

The Kosovo Appraisers Association is trying to speed up the process of drafting the law. In the future it is expected that the appraisal of real estate property will be mandatory for every real estate transaction between parties.

The basic source for a part of the data is found in the state geo-portal http://geoportal.rks-gov.net with cadastral data for plots and orthophotos and is available to everybody for free.

Today, neither Kosovo Appraisers Association nor the Ministry of Finance have a complete list of all licensed appraisers on their web site (it was available few years ago). List is available upon request end justification of its usage. This list is not up to date, it has errors and shortcomings. It does not include primary profession of appraiser nor residence.

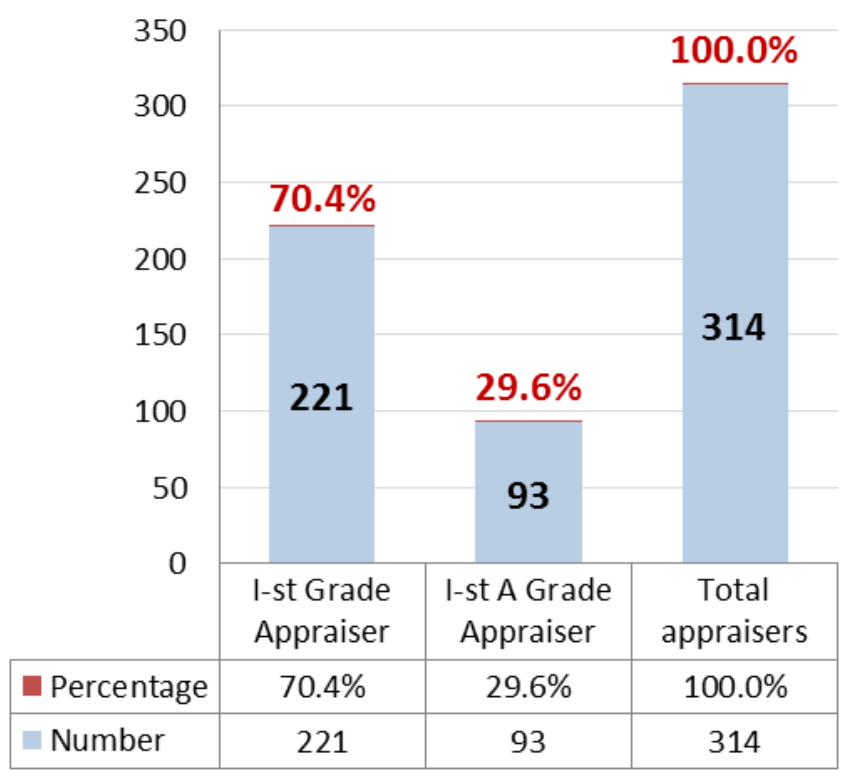

Fig. 2. Number and percentage of issued licenses 


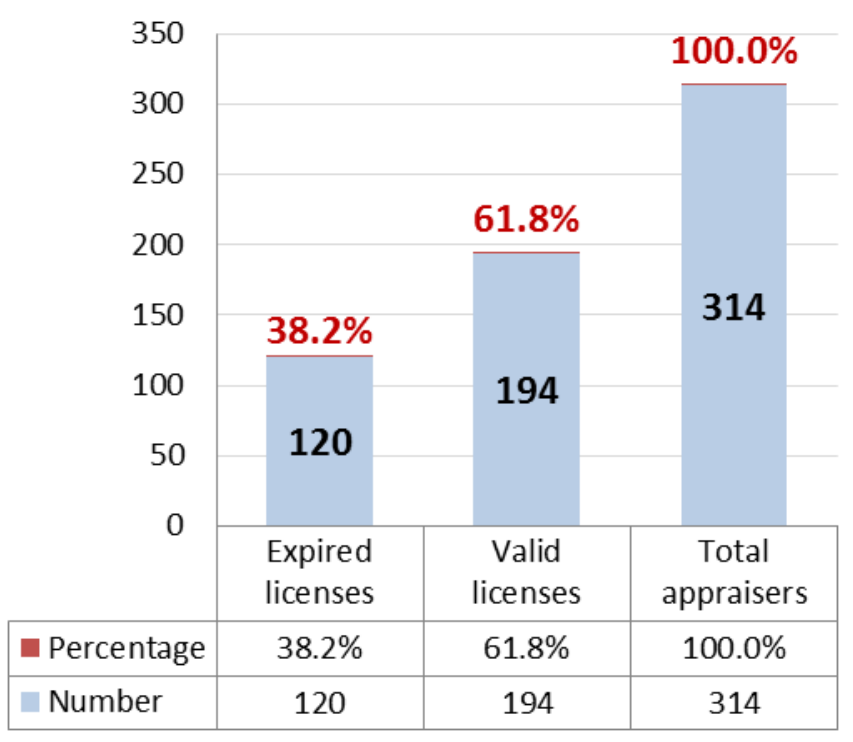

Fig. 3. Number and percentage of license validity

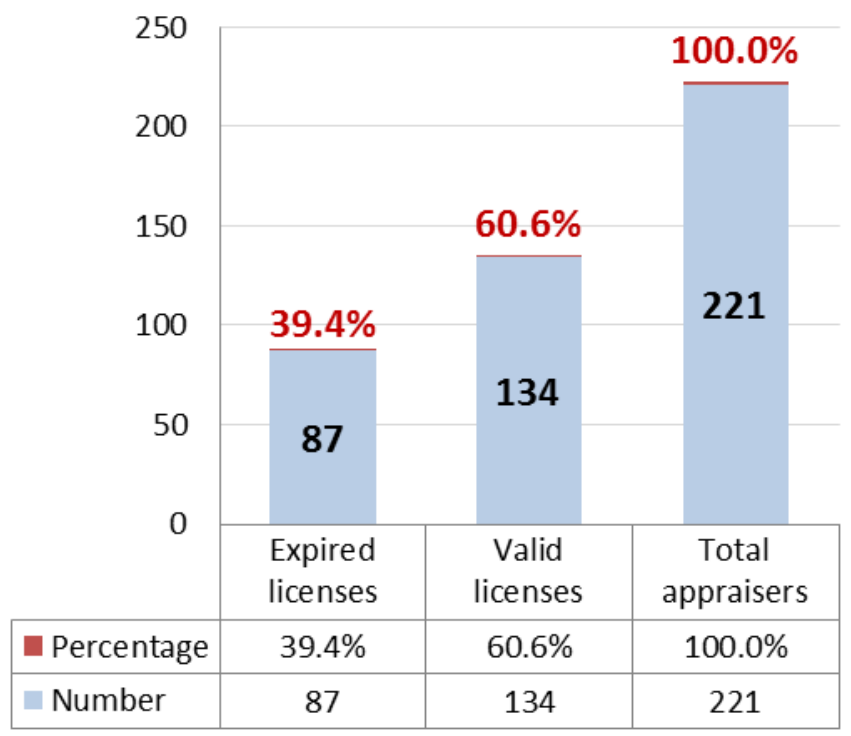

Fig. 4. Number and percentage of I-st Grade licenses 


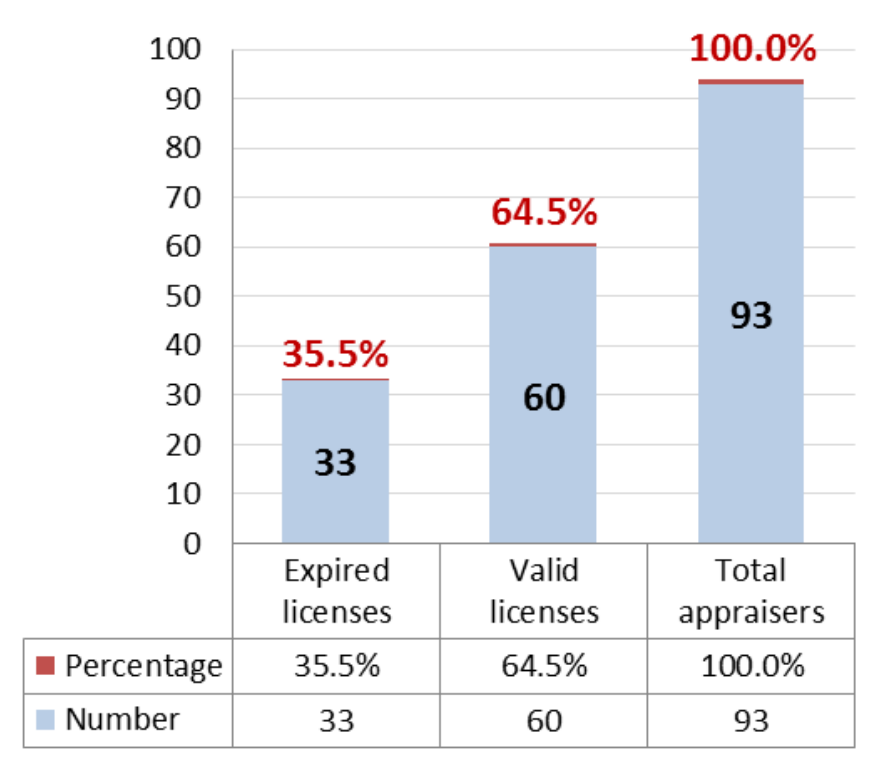

Fig. 5. Number and percentage of I-st A Grade licenses

\section{Challenges}

As a licensed appraiser I will mention main challenges while performing this profession:

- Lack of transaction contracts between seller and buyer

- Transactions with unrealistic value (lower value of the property to lower taxes)

- Property Documentation - on behalf of dead person's name

- Property Documentation - ownership on behalf of the first owner - (no legal transaction from seller to buyer)

- Property Documentation - declaration of ownership by several owners for the same property (same property sold to two or more buyers - not providing any paper work)

- Property Documentation does not represent factual situation of the property (property incurred changes)

- Intervention on real estate value from bank managers for preferred client properties (violation of Code of Ethics)

- Lack of law

- Lack of required appraisal services

- Low prices for appraisal services

\section{Conclusions}

We are in the information age. Today, from the office, we can get information from every corner of the world. Information is power and as such its possessors may seek monetary reward for sharing it. Since the state institutions have transaction data they can create a digital database platform for real estate property sales. Access to this database should be granted to licensed 
appraisers against a reasonable fee. Gathering of information would be fast, accurate and up to date.

In some countries this is done by large companies which deal with property appraisal and are well aware of transactions occurring in a given market.

In the beginning, many eligible persons with enthusiasm spent their money and time going through trainings and tests. Statistics show that today 120 licenses (38.2\%) expired. This number will be even higher and they will not renew their licenses if challenges remain the same.

Main reasons for appraisers to abandon this profession are economical - supply and demand. There is very little demand and supply is very high. Actually market is saturated with licensed appraisers. State can solve this problem by drafting and approving legal framework which requires real estate appraisal for every property transaction. Also state can fix minimal fees similarly as it is defined for notary services.

\section{References}

1. European Valuation Standards 2016, Eighth Edition, TEGoVA - The European Group of Valuers' Associations

2. International Valuation Standards 2017, IVSC - International Valuation Standards Council

3. RICS Valuation - Professional Standards, January 2014

4. Elfrida Alliu: "Bazat e Vlerësimit të Pasurive të Paluajtshme", Tiranë 2011

5. Anton Lezhja: "Vlerësimi i Pasurive të Paluajtshme", Tiranë 2015

6. Ndryshim / Plotësim Nr. 6-1/2015 i Rregullores nr. 6 të datës 11 Tetor 2013 për Procedurat dhe Kriteret e Licencimit për Personat Fizik si Vlerësues të Pronave të Paluajtshme

7. Bordi i Bankës Qendrore të Republikës së Kosovës, Rregullore për Vlerësimin e Pasurive të Paluajtshme, 26.02.2015

8. Udhëzimi Administrativ Mf-Nr. 03/2018 Për Metodologjinë e Vlerësimit, 30.10.2018 